\title{
Natural Environment Pretability of Plapcea Basin For Agriculture
}

\author{
ANCA-LUIZA STANILA* \\ National Research Institute for Soil Science, Agrochemistry and Environment-ICPA, 61 Marasti Blvd., 011464, \\ Bucharest, Romania
}

\begin{abstract}
Plapcea Basin is among the regions nature and diversity of natural territorial complex components provides users obtain optimal agricultural production and income, especially if harnessed effectively, economically and environmentally existing technologies. A productive agriculture is essential prerequisite for sustainable development of agriculture with multiple objectives, further reduce poverty and improve livelihoods, with preserving and protecting the natural resource base. But these are not possible without special research, extensive and often lengthy. On this importance is the paper which deals extensively formation, development and distribution of the soil in the area closely correlated to environmental factors, and pretability for characterization of the natural environment for agricultural region. Since the economic efficiency of agriculture is not possible without the use of all factors of landscape, I referred to the region's agricultural pretability of each component of the environment and therefore soil. A number of factors, however, limit the agricultural production. Therefore Plapcea Basin were outstanding four categories of land, the last with severe restrictions. Eliminating or at least reducing these restrictions is only possible through the application of measures and agropedoameliorative works.
\end{abstract}

Keywords: Plapcea Basin, pretability, environmental factors, texture, agropedoameliorative works

\section{Introduction}

Complex approach to a region opens up deep knowledge of building structures, components of relationships in physical and geographical changes in time and space.

The case was investigated component and leading the scientific knowledge of the entire complex components (factors) natural Plapcea valley basin, which resulted in objective knowledge of potential soil cover.

The morphology of the region is studied through the landscape, analyzed as the result of a long evolution (Conea et al., 1957, 1967) [1,2].

Regarding Cotmeana Piedmont area where the hydrographic basin is located, may be mentioned some geological surveys, soil studies and even geobotanic ones (Popovat et al.,1959) [3]. The geological studies are divided into two categories: some summary, which includes only references to the geological structure and paleogeographic evolution of the region and belong to a large number of specialists from Liteanu et al. (1960, 1971) [4, 5], Oncescu et al. (1957) [6], Dragu (1962) [7], the enhancement of water supplies and building materials in the region that have dealt Parichi $(1970,2001)[8,9]$.

The soil can not be understood and can not be charged if they are not known to qualities and features of the natural environment in which it developed.

The morphology of the region is taken into consideration by which the relief is more specific and analyzed in detail as a result of a long evolution, the types of elements.

Thus, interfluves and valleys are separated with their microforms [10].

$\overline{\text { *email:luizastanila2011@yahoo.com }}$ 
The emphasis is on soil cover. No other natural component does not include in its context space, more implications than soils. The assembly of the Placea Basin pedogenetic factors specific led to the formation of a layer of the soil is quite complex in which are present a number of clearly differentiated types and subtypes, most of them belonging to the class luvisols (77\%). In all likelihood these soils were formed in the development of geographic landscape.

Assessments are made regarding the pretability for agriculture of each component of the environment and thus, on the ground. It works proposing the agropedoameliorative works, to be executed both single and combined with each other.

\section{Materials and methods}

The work consisted of territorial research studied in 1: 10.000 and 1.25.000 for the whole area.

The primary unit of basic research and mapping areas was the soil profile, which allowed studying morphological characteristics of the soils. As a result, soils were classified based on the intrinsic properties respectively soil profile, considering horizons and diagnostic characteristics [11].

Soil profiles were located on the ground so that to form a network of studied points. The method of parallel routes, located almost at equal distances has been used, to cover more or less uniformly the whole working area.

The morphological description of soil profiles was done according to the Romanian System of Soil Taxonomy (SRTS, 2012), ICPA, Bucharest [12].

In order to establish the soils diagnosis, their morphological features have been taken into account, namely the thickness of morphological horizons, color, texture, structure, composition, adhesion, etc.

In modified settings, soil samples of $20 \mathrm{~cm}$ thickness were taken in bags, for the chemical characterization to be carried. In natural (unchanged) settings, soil samples were taken using a metal cylinder of known volume $\left(200 \mathrm{~cm}^{3}\right)$, to characterize the physical and hydro-physical features, as well as the momentary soil moisture [13].

Interpretation of the results has been submitted in accordance with "Methodology developing soil studies", ICPA Bucharest, 1987, provided for in current legislation on the subject [14].

Map making materials were used following map: Romanian soil map, scale 1:200.000, sheet Pitesti and Slatina [15]. Thus, those maps were scanned, then the images were vectorized. He data were then processed using CorelDRAW. For each map, the computer result in a "polygon layer" mapping each polygon representing a territorial unit. Cartographic data validation was done by overlapping polygons layer the source data. Each territorial mapping unit, were entered as attributes: soil genetic unit, the surface texture, the parent material, pedogenetic processes and the relief.

\section{Results and discussions}

The territory we are talking about an area of 25.000 ha is located in the south of the country in content Cotmeana Piedmont, Getic Piedmont subdivision and belongs to Olt County $[16,17]$. The study of the soil cover and the parent material shows that the Plapcea Basin, as in all Cotmeana Piedmont soil formation sediments are relatively varied. From the point of view of pedogenetic, they can be grouped in poorly consolidated rocks (clay, marly clay, clay loam) and mobile rock (gravels, sands, loess-like deposit, etc.). Of these the most widespread have poorly consolidated rocks (Table 1) [18].I

Table 1. Genetic types of parent materials

\begin{tabular}{|c|c|c|}
\hline Landform & Genetic types & Lithological composition \\
\hline Piedmont interfluves and terraces & Alluvial-proluvial deposits & Clay, marly clay, clay loam, loess-like deposit \\
\hline Alluvial cone and glacis & Proluvial deposits & $\begin{array}{c}\text { Clay loam with sands and gravels clay loam, loam } \\
\text { sands and gravels }\end{array}$ \\
\hline Floodplain & Alluvial deposits & Sands, gravels, loamy sand, sandy-loamy \\
\hline Slopes & Deluvial-proluvial deposits & Sandy-loamy, clays often skeletal material \\
\hline
\end{tabular}

In Plapcea Basin, flat surface soils have been developed especially on clay which belong Layers of Candesti and all local marly clay [19]. 
The thickness of these deposits is reduced gradually from north to south. Thus, in the upper part of the Plapcea Basin, near the town Optasani, they get more than $5 \mathrm{~m}$ as up to locality Jitaru at the entrance to the plains fall below $3 \mathrm{~m}[20,21]$.

Both hydrographic network activity and slope processes were conducted in especially on account of yellow clay and layers of Candesti. Currently basin territory belonging Plapcea Basin it consists of piedmont interfluves, terraces, floodplain, glacis, dejection cones and slopes [22].

Like parts of the territory of the relief forms are characterized by certain qualitative and quantitative indices that affects the development of many different pedogeomorphologic processes such as leaching, stagnogleyzation, landslides and collapses (Figure 1).

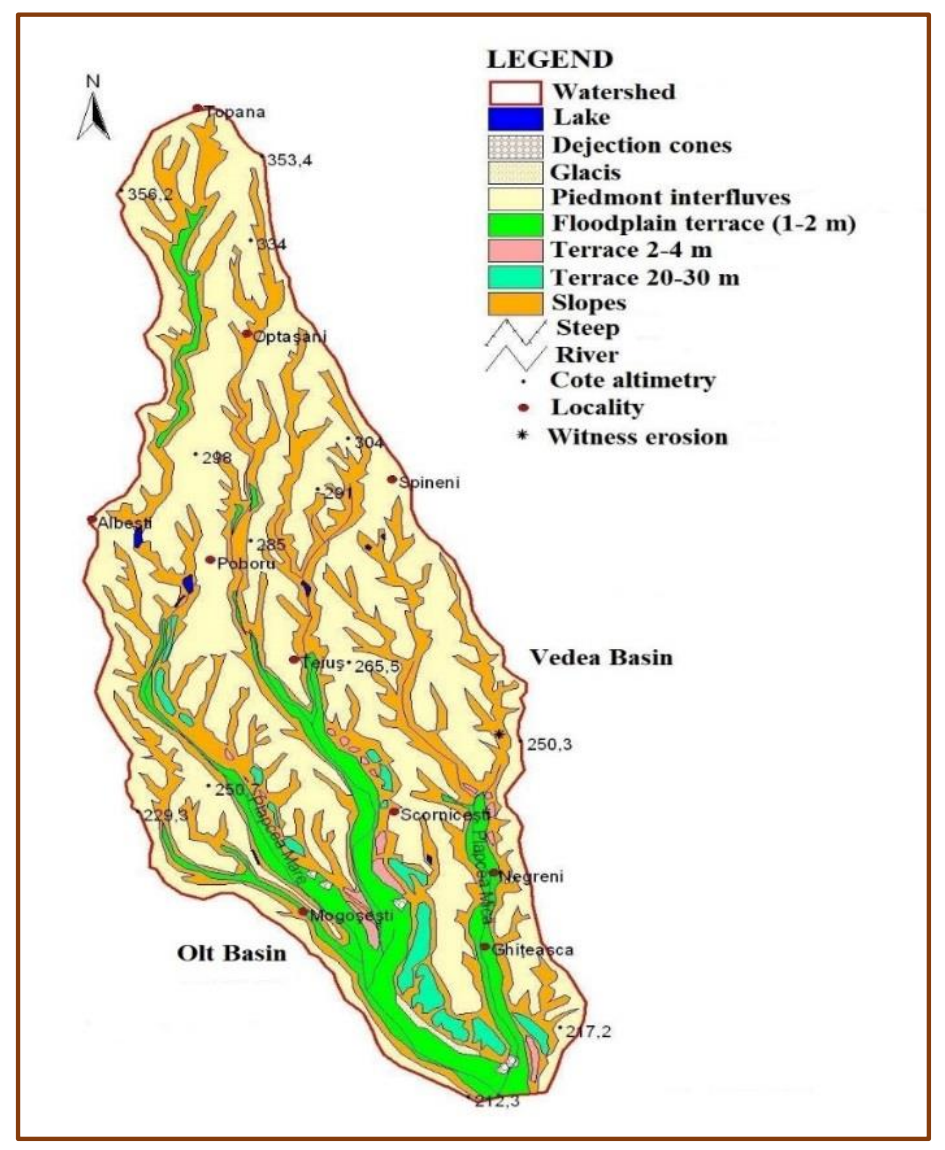

Figure 1. Plapcea Basin. Relief map (Scale $1: 200.000)[15]$

More than $90 \%$ of the studied area is formed interfluves and slopes, terraces around $2 \%$, and other forms of relief with almost $8 \%$. Plapcea Basin, as well as throughout the geographical area of Cotmeana Piedmont it is characterized by a temperate continental climate.

From a climate perspective within which we have been characterized by annual average temperatures between $9^{\circ} \mathrm{C}$ and $10,5^{\circ} \mathrm{C}$ and rainfall is below $700 \mathrm{~mm}(450-700 \mathrm{~mm})$ and are uniformly distributed throughout the year. Thus, during the growing season (april to october) fall between $350-450 \mathrm{~mm}$ and from november to march between 140-250 mm [23].

Plapcea Basin valley forests cover very small areas and consist mainly of Quercus frainetto, that the slopes is associated with $Q$. cerris, while the flat surfaces of the piedmont interfluves, along with changes in the soil cover to Albesti locality north are emerging species Quercus petraea and Fagus sylvatica (Figure 2). 


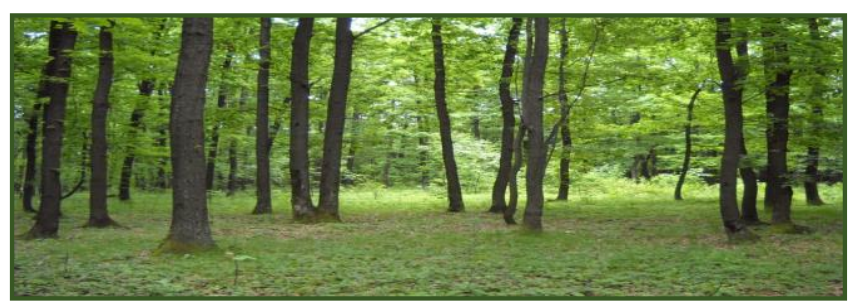

Figure 2. Forest of Quercus

petraea and Fagus sylvatica to Albesti

Sporadic and small areas going south were identified associations of Quercus robur, Carpinus betulus, which does not lack Ulmus foliacea and Acer campestre.

A special role in the formation and development of soil cover of the territory to which we refer it had in order climate, vegetation, topography, parental or rock material, all local stagnant water and groundwater.

When these factors are added during and human influence. Among pedogenetic processes occurring in soils in the Plapcea Basin mention: bioaccumulation, leaching, clay migration, stagnogleyzation and erosion.

Under the influence of simultaneous and associated factors pedogenetic in Plapcea Basin formed a relatively wide range of soils that the Romanian System Soil Taxonomy-2012 belong classes: protisols, cernisols, cambisols, luvisols and hidrisols. Of these luvisols class occupies the largest share. Of these luvisols class occupies the largest share namely $77 \%$ of the territory investigated.

Economic efficiency of agriculture is not possible without the natural resources existing however, that the main environmental factors whose integration creates that ecological, more or less favorable natural various uses.

Only by knowing in detail the potential of natural environmental factors, considered separately and in their integrated complementarism man can intervene consciously capitalizing native land pretability and optimization of the permeability through the most modern farming.

Based on the study of the natural soil cover and assessment of the pretability try some of each component for agriculture and soil environment, as the product of the interaction of environmental factors, it synthesizing the combined action of the ecological factors [24].

\section{Agrolitologic pretability}

The pedogenetic processes, soil parent material gives some of its features. Total porosity, field capacity, permeability, exchangeable base and nutrients are some of the soil properties affected by dowry lithological soil.

Parental materials characteristic of the area they are represented for the most part $(75 \%)$ yellowish silty clays. The size composition prevails, of course the clay fraction (50-60\%), followed by silt (27$34 \%$ ) [25].

They have favored the formation of large areas of luvisols for the most part affected by the excess moisture stagnant, which pose particular challenges in terms of their agricultural use (Figure 3).

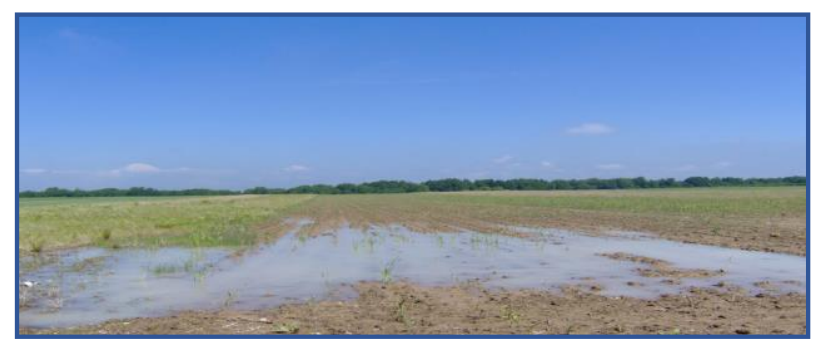

Figure 3. Excess

moisture from rainfall

on typical stagnosols

to Scornicesti

On the terraces, the soils were developed less homogeneous material (loess-like deposit, loamy clays) with a high content of coarse material. 
They permeability middle and allowed the formation of soils (preluvosols) with good pretability to agricultural use.

The inclined surfaces and floodplain they are coated with deluvial-colluvial and alluvial fraction of predominantly sandy, with good permeability.

\title{
Agrogeomorfologic pretability
}

An important feature is the flatness of the Plapcea Basin interfluves piedmont, which allowed a better organization of lots mechanization and fertilizer management in good conditions especially for grain uses.

However exploitation of agricultural land is hampered by quasi horizontal character of the landscape that favor soil with imperfect drainage, excessive wetting, which mostly takes between 15-60 days. All cultures suffer badly, the most sensitive years (Figure 4).

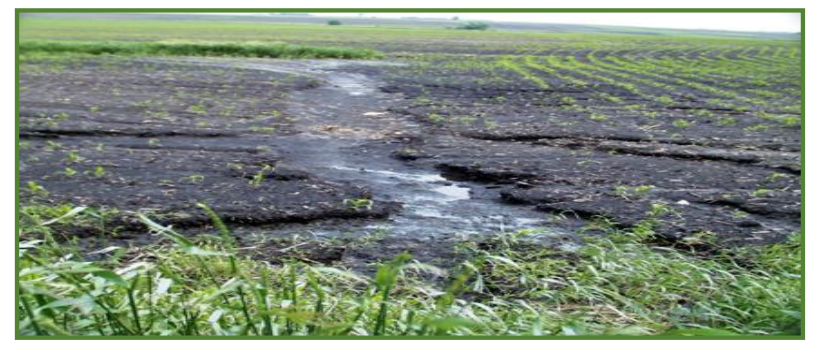

\author{
Figure 4. Stagnogleyzation \\ risk of soil due to the \\ stagnation by rainfall in the \\ interfluves Plapcea- \\ Negrisoara
}

Slopes have a high share of total agricultural area (18.2\% or 5019.5 ha) and are landforms that put the most difficult problems for agricultural use (adapting uses, mechanization, erosion control measures, etc.) due to denudational processes (areolar erosion, landslides, ravines) still active. We refer in particular to the slopes of the main valleys (Plapcea and Negrisoara) [22].

Pretability of these slopes is reduced and sometimes even restrictive for agricultural use, but favorable for growing trees and vineyards, or pasture.

It should also take into account the length of the slope, exhibition and especially their inclination, which promotes erosion. Thus, heavy rainfall in may-june entrain the surface run-off, large amounts of solid material which is deposited at the bottom of the slope, very frequently into the river channel reaching rivers.

\section{Agroclimatic pretability}

Climatic data highlight the availability for agriculture most of the territory. Monthly average temperatures $\left(10,1-22^{\circ} \mathrm{C}\right)$ during the growing season, as the annual $\left(9,0-10,5^{\circ} \mathrm{C}\right)$ are favorable for most uses and cultures.

The average annual precipitation has values between 500-700 $\mathrm{mm}$. However there are years in which they can fall below $400 \mathrm{~mm}$ or increase up to $900 \mathrm{~mm}$. In both cases the values are restrictive. Maximum quantities of the inter-affecting slight unevenness, and the flat surfaces stagnic luvosols or typical stagnosols causes denudational processes and floods.

Large surfaces of ground (about $60 \%$, excluding floodplain) are affected by the excess moisture in the time range of 5-60 days per year, that significant areas of land, often they can not be sown in spring (Figure 5).

\section{Agrohidrologic pretability}

Hydrological regime of the valleys that furrow the investigated area is deficient. More than half of the year, total dry them. Due to the denudation, these valleys are transported suspended soil amounts of materials that are deposited for the most part in the minor beds or in the vicinity thereof. Permanent aquifers not quite meet in the region due to its geological composition, the sands and gravels become 
dominant. Only the floodplain and terraces groundwater is confined to depths between 4-15 m without affecting in any way the soils.

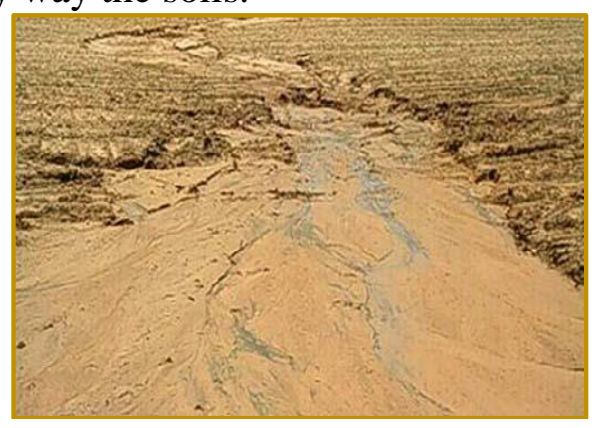

Figure 5. Denudational

processes in soil with

texture clay loam in the

Plapcea Basin

\section{Agropedologic pretability}

Under the joint action of pedogenetic factors, in the Plapcea Basin developed a relatively uniform layer of the soil, which highlights the agropedologic pretability a little varied.

This refers to physical properties, hydro, chemical and even biological properties of soils relative to various categories of agricultural use [24].

Soil texture. For this, they took into account data on the texture of the surface horizon. Thus, the texture loamy, clay-loamy and clay being specific in most luvosols, preluvosols as stagnosols not just provide optimal conditions crops (Figure 6).

Total porosity. Considered in the depth of $20-80 \mathrm{~cm}$, which relates to the assessment of the condition of the soil compaction as well as the need for deep loosening of their present values medium-low (39$51 \%)$. We refer also to luvosols and hidrisols who have less optimal conditions for the development of crops and for some species of trees.

Excess surface moisture affects a large part (38\%) of soils Plapcea Basin, piedmont interfluves corresponding to luvosols, preluvosols and stagnosols. This presents severe limitations for most crops except grassland.

The reaction soil. In determining the productive capacity of land, special importance belongs soil reaction wherein the values of lower $p \mathrm{H} 5.8$ and greater than 8.4 causes reduction.

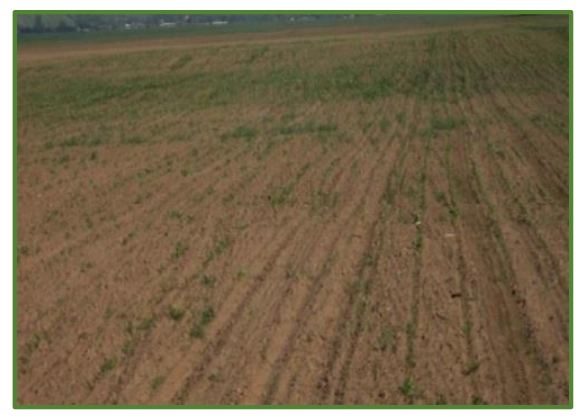

Figure 6. The culture of Zea mays soils textured loamy in Jitaru

In the Plapcea Basin moderate acid reaction (4.5 to 5.8) affect more than 8000 ha of its surface and focuses on the quasi-horizontal land soil whose shell is made up of evolved soils, mostly typical luvosols, albic and stagnic.

The humus content. Low humus land reserve corresponding to a significant part of the piedmont interfluves with luvosols (8105 ha), slopes (5019 ha) and valley (1150.5 ha).

Thus, it can be appreciated that the reserves of humus Plapcea Basin are not satisfactory.

Measures to increase the humus content are welcome (by administration of organic fertilizers or by crop rotation corresponding).

Given the nature and intensity of the restrictive factors for agricultural production, the amplification operation of degradation, Plapcea Basin were outstanding after the pretability of arable land following classes (Figure 7): 


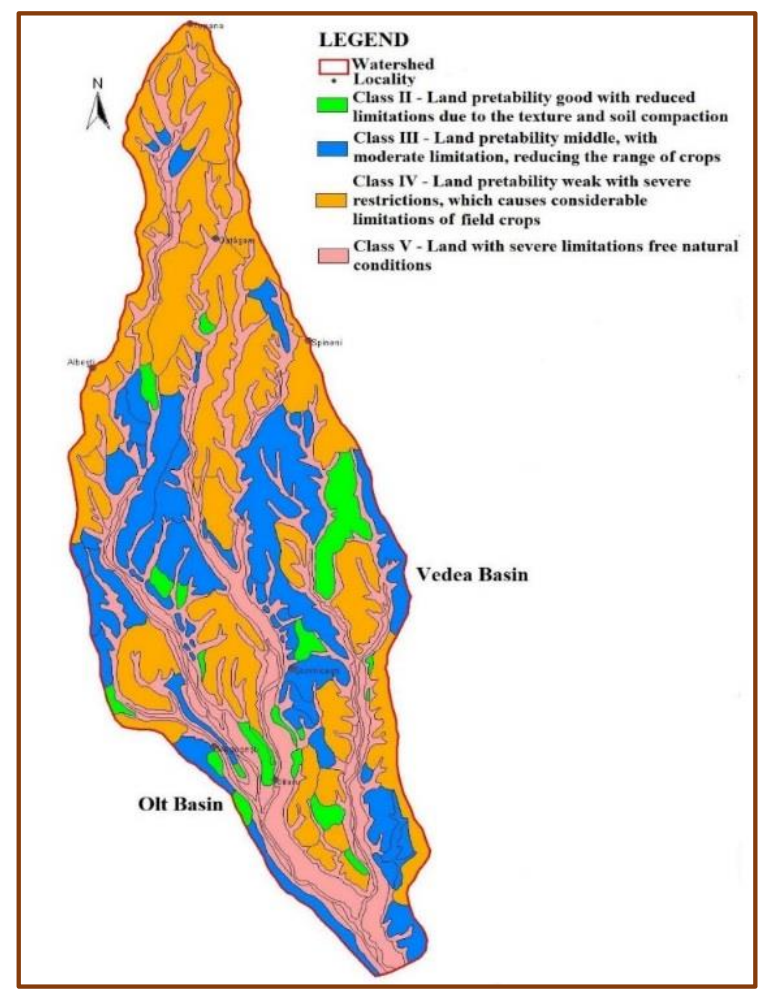

Figure 7. Plapcea Basin. Map group land after pretability arable (Scale $1: 200.000)$ [15]

- Class II - land pretability good with reduced limitations (1325.0 ha) due to the texture and soil compaction.

- Class III - land pretability middle, with moderate limitation (6730.4 ha), reducing the range of crops. Deficiencies are various and relate both to the soil and the global drainage.

- Class IV - land pretability weak with severe restrictions (10167.7 ha), which causes considerable limitations of field crops. They relate to the soil, the unevenness of the land and the global drainage.

- Class V - land with severe limitations (8432.5 ha), free pretability natural conditions.

The limits are in relief sloping to the processes strongly affected by the current geo-morphological (5294.5 ha), inadequate storage state of the fertility of the soil and their greatly reduced and a particularly low soil fertility (3137.5 ha).

\section{Conclusions}

Among the main limiting factors of agricultural production falling as the natural elements we can mention: relief, parent material, climate and soil.

In order to eliminate the negative effects of the limiting factors of agricultural production and thereby improve the productive potential of the belonging Plapcea Basin, we propose a series of pedoameliorative and hidroameliorative works (Table 2, Figure 8).

It is necessary that such improvement works to be performed both single and combined with each other.

Their order of execution is recommended to:

- works for liming to control acidity accented

- deep loosening works for control the deficit of total porosity

- drainage works for control and preventing water logging

- organic fertilization works completed with chemical fertilization

- $\quad$ works to prevent and control soil erosion. 
Table 2. Pedoameliorative and hidroameliorative works

\begin{tabular}{|c|c|c|c|c|}
\hline \multirow[t]{2}{*}{ No. } & \multirow[t]{2}{*}{ Name works } & \multirow[t]{2}{*}{ Soil type } & \multicolumn{2}{|c|}{ Surface } \\
\hline & & & ha & $\%$ \\
\hline 1. & $\begin{array}{c}\text { Pedoameliorative works } \\
\text { - Liming and ameliorative } \\
\text { fertilization } \\
\text { - Ameliorative fertilization } \\
\text { - Current fertilization } \\
\text { - Current fertilizer and deep } \\
\text { plowing }\end{array}$ & $\begin{array}{c}\text { Stagnic luvosols } \\
\text { Stagnic melanic luvosols } \\
\text { Albic stagnic luvosols } \\
\text { Albis stagnic melanic luvosols } \\
\text { Typical stagnosols } \\
\text { Calcaric phaeozems } \\
\text { Typical preluvosols } \\
\text { Molic preluvosols } \\
\text { Molic stagnic preluvosols } \\
\text { Stagnic preluvosols } \\
\text { Stagnic melanic preluvosols }\end{array}$ & $\begin{array}{c}414.5 \\
3575.0 \\
550.0 \\
3567.7 \\
2065.5 \\
687.3 \\
235.2 \\
412.5 \\
687.5 \\
1370.5 \\
4672.0 \\
\end{array}$ & $\begin{array}{c}1.50 \\
13.40 \\
2.06 \\
13.40 \\
7.83 \\
2.58 \\
0.88 \\
1.54 \\
2.60 \\
5.13 \\
17.50 \\
\end{array}$ \\
\hline 2. & $\begin{array}{c}\text { Hidroameliorative works } \\
\text { - Improving the aerohidric } \\
\text { regime by throwin plowing with } \\
\text { subsoiling } \\
\text { - Regularization of rivers, } \\
\text { ameliorative fertilization }\end{array}$ & $\begin{array}{c}\text { Stagnic luvosols } \\
\text { Stagnic melanic luvosols } \\
\text { Albic stagnic luvosols } \\
\text { Albis stagnic melanic luvosols } \\
\text { Typical stagnosols } \\
\text { Entic aluviosols } \\
\text { Eutric aluviosols } \\
\text { Aluvic eutricambosols } \\
\end{array}$ & $\begin{array}{c}414.5 \\
3575.0 \\
550.0 \\
3567.7 \\
2062.5 \\
175.0 \\
1100.0 \\
1862.5 \\
\end{array}$ & $\begin{array}{c}1.50 \\
13.40 \\
2.06 \\
13.40 \\
7.83 \\
0.65 \\
4.12 \\
6.98 \\
\end{array}$ \\
\hline 3. & $\begin{array}{l}\text { Soil management erosion works } \\
\text { - Protection afforestation } \\
\text { - Establishment of a sod } \\
\text { - Facilities at the head of } \\
\text { ravines and torrents } \\
\text { - Contour plowing }\end{array}$ & $\begin{array}{c}\text { Distric regosols } \\
\text { Typical preluvosols and eroded preluvosols } \\
\text { Typical preluvosols, eroded preluvosols and } \\
\text { erodosols }\end{array}$ & $\begin{array}{c}275.5 \\
2256.0 \\
2763.5\end{array}$ & $\begin{array}{r}1.04 \\
8.45 \\
10.34 \\
\end{array}$ \\
\hline
\end{tabular}

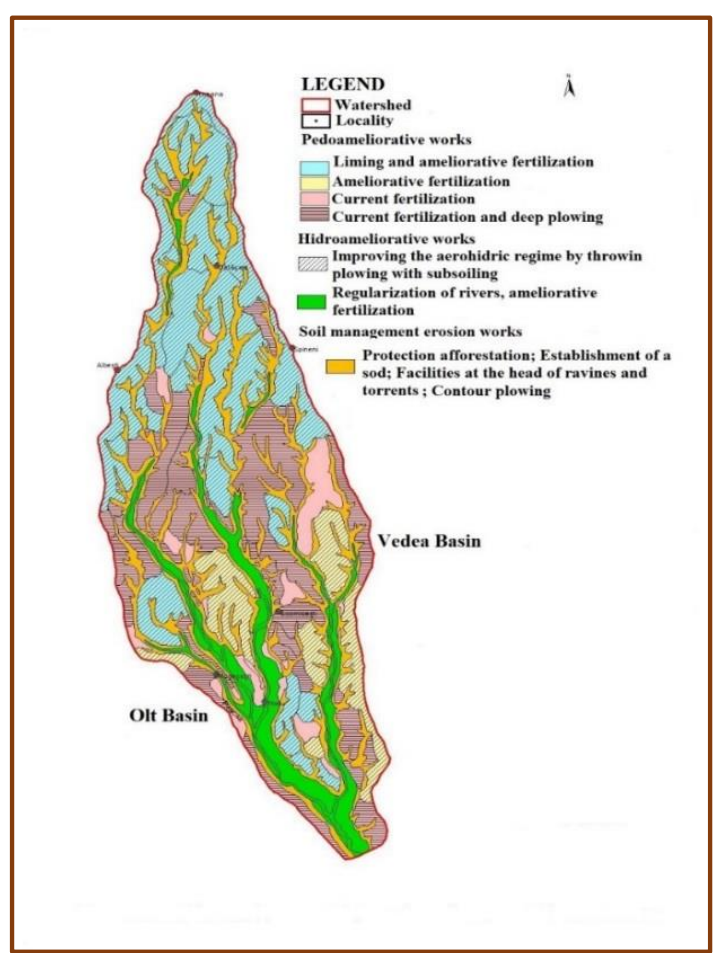

Figure 8. Plapcea Basin.

Map requirements pedoameliorative and hidroameliorative (Scale $1: 200.000)$ [15]

Acknowledgement: I am very thankful to Department research in soil science, agrochemical and environmental protection, Laboratory of soil sciences and sustainable development for providing the necessary facilities to carry out this work through Research contract No. 17/2019. 


\section{References}

1.CONEA, ANA, VASILESCU, P., GHINEA, P., Vertisols in Romanian Plain Western, Annals of the Institute for Research Soil, Vol. XXXIX, Bucharest, 1957.

2.CONEA, ANA, POPOVAT, ANGELA, RAPAPORT, CAMELIA, Les sols „Smolnitzas” (vertisols) et leur formes de transition vers d'autres types au sud de la Roumanie, 8-th International Congres of soil Science, Transaction, Vol. V, Bucharest, 1967.

3.POPOVAT, A., RAPAPORT, C., DRAGU, I., Erosion processes in the west Cotmeana Platform, Geological Committee, Technical Studies, Series C, no. 11, Bucharest, 1959.

4.LITEANU, E., Quaternary map of the Romanian extra-Carpathian, Archive Geological Institute of Romania, Series Geology and Geography, No. 1, Bucharest, 1960.

5.LITEANU, E., GHENEA, C., MIHAILA, N., GIURGEA, R., About geology and hydrogeology Cotmeana Platform, D.S. Geological Institute of Romania, Series H, Bucharest, 1971.

6.ONCESCU, N. DRAGOS, V., MOTAS I., Preliminary Report on the problem of drinking water in the region Cotmeana county Arges and Olt, Archive Geological Institute of Romania, Bucharest, 1957.

7.DRAGU, I., Geobotanical research in Cotmeana Platform, D.S. Geological Committee, XLIII, Bucharest, 1962.

8.PARICHI, M., Soil exploration in Cotmeana Piedmont, Archive ICPA, Bucharest, 1970.

9.PARICHI, M., Cotmeana Piedmont - physical-geographical study on particular soils, Publisher of Tomorrow Foundation Romania, Bucharest, 2001, 200 p.

10.DUCHAUFOUR, PH., Precise de Pédologie, II-e edition, Publisher Masson, Paris, 1970.

11.*** Romanian system of soil classification, ICPA, Bucharest, 1980.

12.FLOREA, N., MUNTEANU, I., RUSU, C., DUMITRU, M., IANOS, GH., RADUCU DANIELA, ROGOBETE GH., TARAU, D., Romanian System of Soil Taxonomy (SRTS), Publisher SITECH, Craiova, 2012, p. 206.

13.CANARACHE, A., Soil physics, Ceres Publishing House, Bucharest, 1990, p.268.

14.*** Development methodology soil studies (3 Volume), ICPA, Bucharest, 1987, 726 p.

15.***, Romanian soil map, scale 1:200.000, sheet Pitesti and Slatina, ICPA, Bucharest, 1971.

16.ASVADUROV, H., VASILESCU, P., Research soil recognition hilly region of Topolog, Vedea and Arges, D. S. Geological Committee, XLVII, Bucharest, 1959.

17.BORDEI, N., BORDEI, ECATERINA, Contributions to the knowledge genesis Piscupia complex, Soil Science, Vol. 9, no. 1, 1971.

18.CARSTEA, ST., MATEESCU, S., Research soil from Jiu and Olt River, D. S. Geological Committee, XLII, Bucharest, 1955.

19.BLAGA, GH., FEODOR, F., RUSU, I., UDRESCU, S., VASILE, D., Pedology, Academic Press Publishing House, Cluj Napoca, 2005.

20.CERNESCU, N., Facteur de climat et zones de sol en Roumanie, Studies and researches, Series C, no. 2, Geological Institute of Romania, Bucharest, 1934.

21.PARICHI, M., STANILA, ANCA-LUIZA, CRUCERU, N., Soils main relief units in Romania, Romania for Tomorrow Publishing House, Bucharest, 2006, 179 p.

22.STANILA, ANCA-LUIZA, PARICHI, M., CRUCERU, N., Pedogenetic soil enfranchisement of the relict Getic Piedmont, Scientific Papers, UASVM Bucharest, Series A, Vol. LIII, UASVM Bucharest, 2010, p. 41-46.

23.The climate of Romania, National Meteorological Administration, Romanian, Academy Publishing House, Bucharest, 2008, 365 p.

24.ISPAS, ST., STANILA, ANCA-LUIZA, Romanian soils, Publisher Valahia University Press, Targoviste, 2015, $246 \mathrm{p}$.

25.CERNESCU, N., Classification of soils with excess moisture, Pedology researches, Publishing Academy, Bucharest, 1961.

Manuscript received: 13.03 .2019 